\title{
Evaluation of Phytotoxicity for Compost from Organic Fraction of Municipal Solid Waste and Paper \& Pulp Mill Sludge
}

\author{
Manjula Gopinathan ${ }^{1}$, Meenambal Thirumurthy ${ }^{2}$ \\ ${ }^{I}$ Department of Civil Engineering, Karpagam University, India \\ ${ }^{2}$ Department of Civil Engineering, Government College of Technology, India \\ crossref $\mathrm{http}: / / \mathrm{dx}$. doi.org/10.5755/j01.erem.59.1.922
}

(received in December, 2011, accepted in March, 2012)

\begin{abstract}
The compost obtained from composting organic fraction of Municipal solid waste, Paper \& Pulp mill sludge and saw dust using different initial mix ratios $(1: 3,1: 6,1: 9)$ was used to evaluate phytotoxicity of green gram (Vigna radiata) using a seed germination method. The tests were repeated for the compost obtained from organic fraction of MSW and saw dust without the addition of sludge. The control germination test was carried out using deionised water. The results showed that composting generally reduced the phytotoxicity of the mixtures. A germination index was the highest in the mix ratio of 1:9 in the compost obtained from the addition of paper \& pulp mill sludge and a germination index was the highest in the mix ratio of 1:6 in the compost obtained without the addition of sludge. The germination percentage, germination index and vigour index values were relatively higher in the compost obtained with the addition of paper \& pulp mill sludge. The vigour index was found to be maximal in the mix ratio of 1:3 from the compost obtained with the addition of sludge.
\end{abstract}

Keywords: Municipal solid waste, paper \& pulp mill sludge, phytotoxicity, germination index, vigour index.

\section{Introduction}

Paper mill sludge is an inevitable product of the paper making process. De-inking sludge is that which is produced as a result of paper recycling. This sludge comprises a cocktail of inks, fillers, weak and short paper fibres that are stripped off the recovered paper during its conversion into new paper. In recent years, paper mills have striven to put their sludge byproducts to positive use. Incinerations for energy recovery and application to land as a soil conditioner have been the two most practiced options. The land spreading of paper mill sludge, however, is coming now under increased scrutiny and it is believed that such practices are likely to become more heavily regulated in future. Issues arise because of high carbon to nitrogen ratios and high BODs of the sludge which can lead to short term nitrogen sequestration in the field. There are also management issues associated with handling, transport, stock-piling and odour control. Pre-treating the sludge through composting alleviates most of these issues. Composting the sludge could also open up new market opportunities, for example, peat-free compost for the container-grown market and the amateur gardening markets.

Paper mill sludge was effectively composted in the past. That technology was largely based on windrows and aerated piles with practitioners tending to co-compost the sludge with animal manures to provide a source of nitrogen. Composting is considered one of the most suitable approaches for disposing of solid waste and for increasing the amount of organic matter that can be used to restore and preserve the environment. It may be defined as the biological decomposition and stabilization of organic substrates, under conditions that allow development of thermophilic temperatures as a result of biologically produced heat, to produce a final product that is stable, free of pathogens and plant seeds and can be beneficially applied to land. Paper 
mill sludge was successfully composted in the past, though both nitrogen and structural amendments are generally needed to affect the process. However, traditional composting routes for treating the sludge (i.e. windows, aerated piles and direct feed to vermiculture) are limited by their high space requirements. It is considered that emerging in-vessel technologies for more rapid composting would help alleviate those throughput constraints. If unstable or immature compost is applied, it can induce anaerobic conditions, in the same way as the micro-organisms utilise $\mathrm{O} 2$ in the soil pores to break down the material (Mathur et al. 1993).

Another problem associated with the application of immature compost is the release of phytotoxic compounds during the composting process (Hue and Liu 1995). The terms 'stability' and 'maturity', being conceptually different, are both commonly used to define the degree of decomposition of organic matter during the composting process. Compost stability refers to the level of activity of the microbial biomass which can be determined by $\mathrm{O} 2$ uptake rate, $\mathrm{CO} 2$ production rate or by the heat released as a result of microbial activity (Iannotti et al. 1994; Conti et al. 1997). Compost maturity refers to the degree of decomposition of phytotoxic organic substances produced during the active composting stage $(\mathrm{Wu}$ et al. 2000). The objective of this work was to evaluate the effect of water extracts from different mixtures of compost from composting organic fraction of Municipal solid waste, paper \& pulp mill sludge and saw dust in the germination process and root and shoot growth of green gram seeds (Vigna radiata) in order to determine their phytotoxicity. The tests were repeated for compost obtained from organic fraction of MSW and saw dust without the addition of sludge. The control germination test was carried out using deionised water as the control.

\section{Materials and methods}

The study was conducted at the Vellalur Composting yard of Coimbatore corporation, Coimbatore, India.

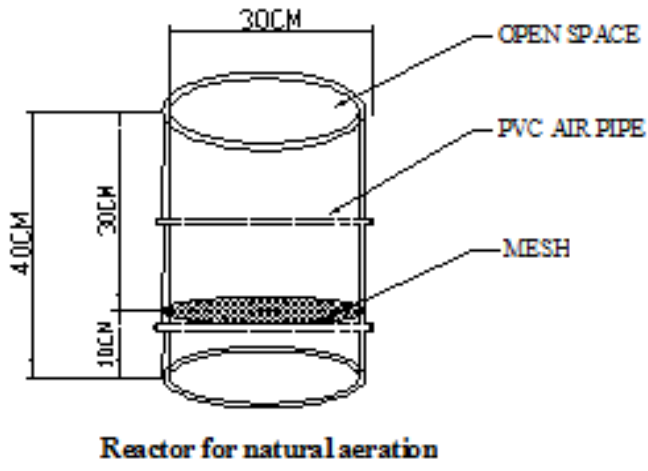

Fig. 1. Reactor's diagram

In this study, drums made of PVC are used as reactors, as indicated in Fig.1. They are single compartment units. Reactor consisted of 2 aeration tubes of 1 "diameter $(2.45 \mathrm{~cm})$ at a height of $15 \mathrm{~cm}$ below the top level and $10 \mathrm{~cm}$ above the bottom to provide sufficient aeration. A mesh is provided at 10 $\mathrm{cm}$ height from the bottom of the reactor above the aeration tube to provide uniform air distribution in the reactor. It also helped to prevent rodent and insects from entering the reactor.

Aerator tubes consisted of small perforations of $3 \mathrm{~mm}$ diameter throughout the tube at a uniform interval of $3 \mathrm{~cm}$. The organic fraction of MSW was collected from Vellalore Municipal composting yard and saw dust from saw mills near Kinathukadavu, Coimbatore. Paper and pulp mills sludge was obtained from Amaravathy paper and pulp mills, Udumalpet. The initial characteristics of the municipal solid waste and paper and pulp mill sludge are indicated in Tables 1and 2, respectively.

Table 1. Initial characteristics of biodegradable fraction of Municipal solid waste

\begin{tabular}{|c|l|c|}
\hline Sl.No & Parameters & Value \\
\hline 1 & Temperature $\left({ }^{0} \mathrm{C}\right)$ & 28.3 \\
\hline 2 & Moisture content $(\%)$ & 35.5 \\
\hline 3 & $\mathrm{pH}$ & 9.43 \\
\hline 4 & Bulk Density & 1.66 \\
\hline 5 & Organic Carbon $(\%)$ & 31.86 \\
\hline 6 & Percentage of Organic Matter & 73.24 \\
\hline 7 & Electrical Conductivity $(\mathrm{ds} / \mathrm{m})$ & 1.55 \\
\hline 8 & Phosphates $(\%)$ & 0.362 \\
\hline 9 & Potassium $(\%)$ & 2 \\
\hline 10 & $\mathrm{C} / \mathrm{N}$ & 40.31 \\
\hline
\end{tabular}

Table 2. Initial characteristics of paper and pulp mill secondary sludge

\begin{tabular}{||c|l|c|}
\hline Sl.No & Parameters & Value \\
\hline 1 & Temperature $\left({ }^{0} \mathrm{C}\right)$ & 29.3 \\
\hline 2 & Moisture content $(\%)$ & 49.64 \\
\hline 3 & $\mathrm{pH}$ & 7 \\
\hline 4 & Organic Carbon(\%) & 23.28 \\
\hline 5 & $\begin{array}{l}\text { Percentage of Organic } \\
\text { Matter }\end{array}$ & 40.14 \\
\hline 6 & $\begin{array}{l}\text { Electrical } \\
\text { Conductivity }(\mathrm{ds} / \mathrm{m})\end{array}$ & 0.256 \\
\hline 7 & Phosphates $(\%)$ & 0.368 \\
\hline 8 & Potassium $(\%)$ & 1.8 \\
\hline
\end{tabular}

The materials were mixed in different proportions manually with the addition of effective micro-organisms as indicated in Table 3 and loaded into the reactors. Turning was done with the help of a wooden rod uniformly on alternate days to provide air for the microbes digesting the organics. The major composition of the waste included vegetable and fruit waste. A $100 \mathrm{ml}$ solution of effective microorganisms including Phospobacteria, Azospirillum lipoferum, Acetobacter aerogens, Trichodema viridi was added to the reactors during loading. $400 \mathrm{ml}$ of deionised water was also added initially and these reactors were watered on alternate days to keep the 
moisture level at an optimum range from $55 \%$ to $60 \%$. The final compost in the reactors was evaluated for its stability based on the temperature, $\mathrm{Ph}$, colour and odour, $\mathrm{C} / \mathrm{N}$ ratio at the end of 30 days of composting. The results are tabulated in Table 5 .

Table 3. Mixture specification for compost $1 A, 1 B$ and $1 C$

\begin{tabular}{|l|l|l|l|}
\hline Reactor & $1 \mathrm{~A}$ & $1 \mathrm{~B}$ & $1 \mathrm{C}$ \\
\hline Mix Ratio* & $1: 3$ & $1: 6$ & $1: 9$ \\
\hline Saw Dust(kg) & 2.5 & 1.4 & 1 \\
\hline OFMSW (kg) & 5 & 5 & 5 \\
\hline Paper and Pulp mill sludge(kg) & 2.5 & 3.6 & 4 \\
\hline EM(m) & 100 & 100 & 100 \\
\hline
\end{tabular}

*Saw dust: (OFMSW+ paper and pulp mill sludge)

Table 4. Mixture specification for compost $2 A, 2 B$ and $2 C$

\begin{tabular}{|c|c|c|c|c|}
\hline Reactor & Mix Ratio* & $\begin{array}{c}\text { Saw Dust } \\
\text { (kg) }\end{array}$ & $\begin{array}{c}\text { OFMSW } \\
\text { (kg) }\end{array}$ & $\begin{array}{c}\text { EM } \\
(\mathbf{m l})\end{array}$ \\
\hline 2A & $1: 3$ & 2.5 & 7.5 & 100 \\
\hline 2B & $1: 6$ & 1.4 & 8.6 & 100 \\
\hline 2C & $1: 9$ & 1 & 9 & 100 \\
\hline \multicolumn{5}{|c}{ * Saw dust: OFMSW }
\end{tabular}

Table 5. Final compost characteristics

\begin{tabular}{|l|c|c|c|c|c|c|}
\hline Parameters & $\mathbf{1 A}$ & $\mathbf{1 B}$ & $\mathbf{1 C}$ & $\mathbf{2 A}$ & $\mathbf{2 B}$ & $\mathbf{2 C}$ \\
\hline $\begin{array}{l}\text { Temperature } \\
\left({ }^{\circ} \mathrm{C}\right)\end{array}$ & 27 & 28 & 27 & 28 & 28 & 28 \\
\hline $\mathrm{pH}$ & 7.4 & 7.4 & 7.5 & 7.5 & 7.5 & 7.5 \\
\hline $\begin{array}{l}\text { Bulk density } \\
(\text { gm cc })^{-1}\end{array}$ & 0.62 & 0.93 & 0.72 & 1.02 & 0.99 & 1.02 \\
\hline $\begin{array}{l}\text { Total organic } \\
\text { carbon }(\%)\end{array}$ & 16.6 & 18.03 & 19.8 & 17.2 & 22.5 & 19.4 \\
\hline $\begin{array}{l}\text { Total Nitrogen } \\
(\%)\end{array}$ & 0.874 & 0.89 & 1.07 & 0.98 & 1 & 1.01 \\
\hline $\mathrm{C} / \mathrm{N}$ & 18.9 & 20.26 & 18.5 & 17.55 & 22.5 & 19.2 \\
\hline \hline
\end{tabular}

\section{Germination test}

A modification of the "paper towel" method described by Fages and Arsac (1991) was used: green gram seeds (Vigna radiata) were placed on a single, wet paper towel, spread on a parafilm, rolled, sealed and placed on the bottom of a container. This test consists of germinating green gram on paper towels that have been moistened with a liquid extracted from the compost to be tested and with water for a control.

All experiments were performed in a randomised design in 4 replicates. Each replicate consisted of 10 seeds. Results are the means of all experiments. Seed germination and the length of the longest root and shoot produced by the seeds were measured after $72 \mathrm{~h}$ in all the extracts and they were compared with those of the water control. The germination index (GI) was obtained by multiplying germination $(\mathrm{G})$ and relative root growth (RRG), both expressed as percentage (\%) of the control values. This index has proven to be the most sensitive parameter, capable of detecting low levels of toxicity which affect the root growth, as well as high toxicity levels which affect the germination (Tiquia and Tam 1998).

$\mathrm{GI}=(\mathrm{G} \% \times \mathrm{RRG} \%) \times 100$

where:

G\% - (number of seeds germinated in a sample / number of seeds germinated in the control) $\times 100$;

RRG\% - (mean root length in a sample / mean root length in the control) $\times 100$;

VI - Germination \%x (mean root length+ mean shoot length).

\section{Results and Discussion}

The results of seed germination test after 72 hours for the four replicates containing 10 seeds in each compost mix are shown in Table 6.The summary of results is presented in Table 7 .

The GI values in composting mixtures of initial mix ratios of 1:3, 1:6 and 1:9 were 87.07, $84.06,97.3$ on day 3 , in the compost obtained from reactors 1A, 1B and $1 \mathrm{C}$, respectively (Table 5), Similarly the GI values obtained from reactors $2 \mathrm{~A}, 2 \mathrm{~B}$ and $2 \mathrm{C}$ were $77.25,88.7$ and 88.43 , respectively (Table 5). Zucconi et al. (1981) reported that a GI value of more than $80 \%$ is an indication of phytotoxic-free and mature compost. Similar suggestions were also reported by Tiquia and Tam (1998). The GIs in the composting mixtures of initial mix ratios 1:3, 1:6 and 1:9 were over $80 \%$ during the composting. The GI value was maximal $(97.3 \%)$ in reactor $1 \mathrm{C}$ with a mix ratio of 1:9. The seed germination $\%$ and vigour index were the highest in reactor $1 \mathrm{~A}$ with a mix ratio of $1: 3$ containing compost from OFMSW and Paper \&pulp mill sludge. The relatively low germination value in $2 \mathrm{~A}$ may be attributed to the release of toxic concentration of ammonia and low molecular weight short chain volatile fatty acids, primarily acetic acid (Fang et al. 1999).

\section{Conclusions}

The physicochemical and phytotoxicity changes during the reactor composting of OFMSW, paper \& pulp mill sludge and sawdust have been investigated at initial mix ratios of 1:3,1:6 and 1:9. The final characteristics indicate the stability and usability of the compost in all the reactors with paper \& pulp mill sludge. The final GI in composting mixture of reactors $1 \mathrm{~A}, 1 \mathrm{~B}$ and $1 \mathrm{C}$ was over $80 \%$; however, the GI in the composting mixtures of mix ratio $1: 3$ in reactor $2 \mathrm{~A}$ was not over $80 \%$ during the test. The stability and maturity in the composting mixture of initial mix ratio 1:9 was superior to those in composting mixtures of initial $\mathrm{C} / \mathrm{N}$ ratio 
of $1: 3$ and $1: 6$. The results of the current work indicate the necessity to stabilize the compost before its application to agricultural soil in order to avoid environmental problems and phytotoxicity.
Composted paper \& pulp mill sludge and organic fraction of Municipal solid waste are a valuable source of organic matter, nitrogen, phosphorus and other nutrients.

Table 6. $\quad$ Experimental results of seed

\begin{tabular}{|c|c|c|c|c|c|c|c|c|c|c|}
\hline \multirow{2}{*}{$\begin{array}{c}\text { Comp } \\
\text { ost }\end{array}$} & \multicolumn{10}{|c|}{ NUMBER OF SEEDS } \\
\hline & 1 & 2 & 3 & 4 & 5 & 6 & 7 & 8 & 9 & 10 \\
\hline
\end{tabular}

\begin{tabular}{|l|l|l|l|l|l|l|l|l|l|l|l|l|l|l|l|l|l|l|l|} 
RL & SL & RL & SL & RL & SL & RL & SL & RL & SL & RL & SL & RL & SL & RL & SL & RL & SL & RL & SL \\
\hline
\end{tabular}

\begin{tabular}{l|l|l|l|l|l|l|l|l|l|l|l|l|l|l|l|l|l|l|l|l|l|}
\hline & $\mathbf{1}$ & 13.2 & 11.5 & 9.1 & 12.5 & 11.7 & 10.9 & 13.5 & 11.4 & 9.9 & 11.9 & 12.8 & 11.2 & 12.7 & 11.1 & 12.3 & 11.6 & 12.1 & 11.8 & 13.3 & 11.4 \\
\hline
\end{tabular}

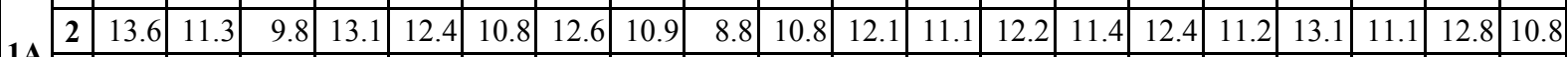

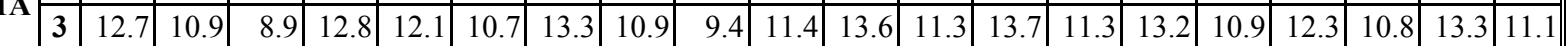
\begin{tabular}{|l|l|l|l|l|l|l|l|l|l|l|l|l|l|l|l|l|l|l|}
\hline 4 & 12.1 & 11.2 & 9.6 & 13.3 & 12.4 & 10.9 & 13.8 & 10.8 & 9.2 & 11.2 & 13.1 & 11.2 & 13.4 & 11.1 & 13.6 & 10.9 & 12.9 & 10.8 \\
\hline
\end{tabular}

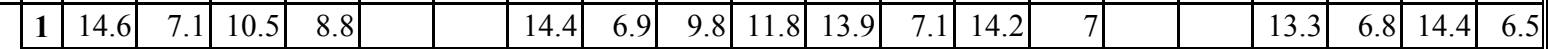

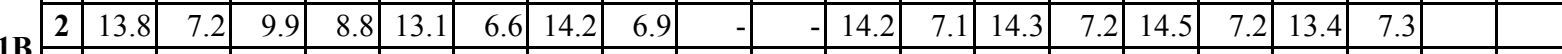

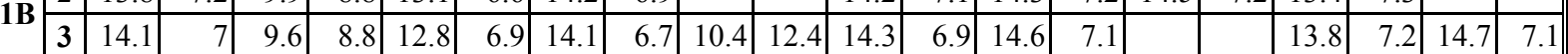

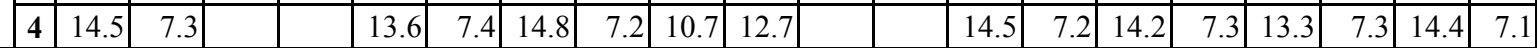

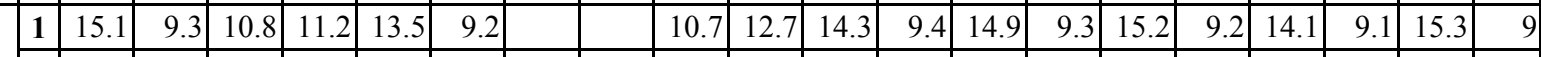

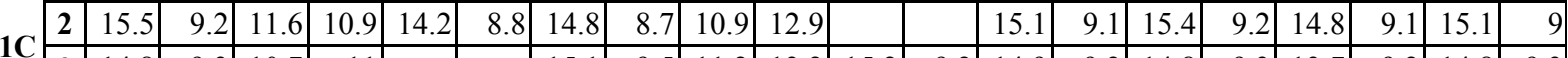

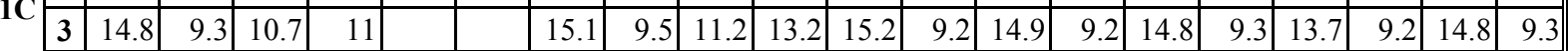

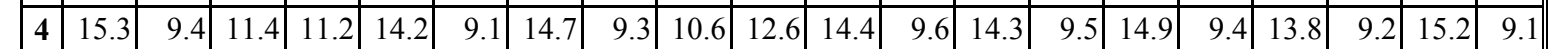

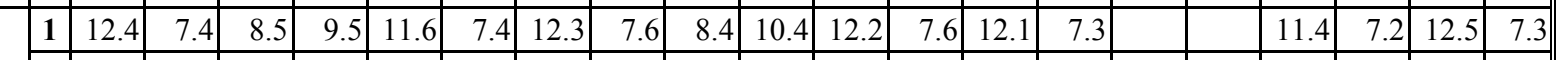

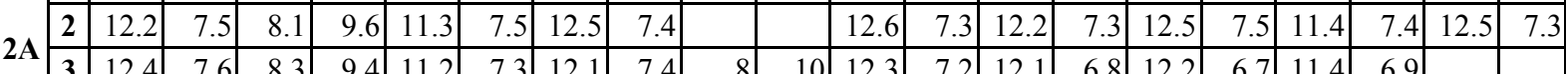
\begin{tabular}{|l|l|l|l|l|l|l|r|r|r|r|r|r|r|r|r|r|r|r|r|r|r|}
\hline $\mathbf{3}$ & 12.4 & 7.6 & 8.3 & 9.4 & 11.2 & 7.3 & 12.1 & 7.4 & 8 & 10 & 12.3 & 7.2 & 12.1 & 6.8 & 12.2 & 6.7 & 11.4 & 6.9 & & \\
\hline $\mathbf{4}$ & 12.5 & 7.1 & & & 11.4 & 7.2 & 12.2 & 7.4 & 8 & 10 & 11.9 & 7.6 & 11.8 & 7.7 & 11.7 & 7.8 & 10.9 & 7.9 & 12.1 & 8 \\
\hline
\end{tabular}

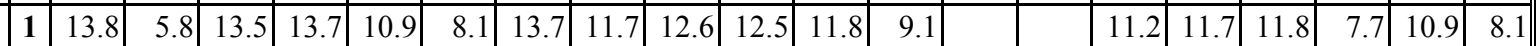

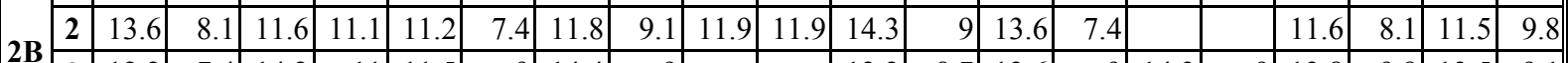

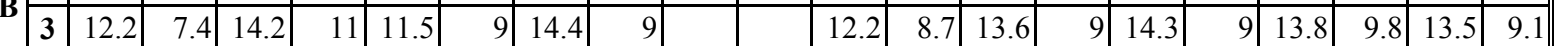

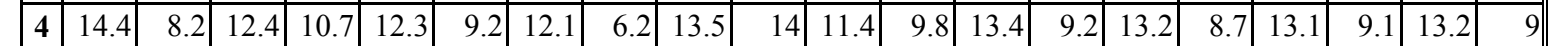

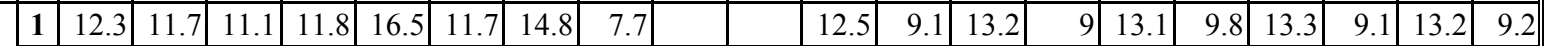

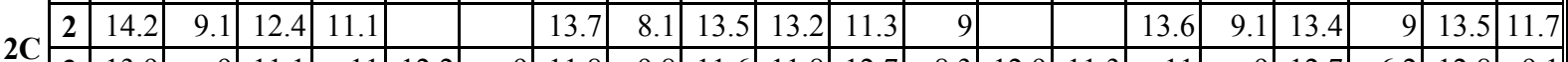

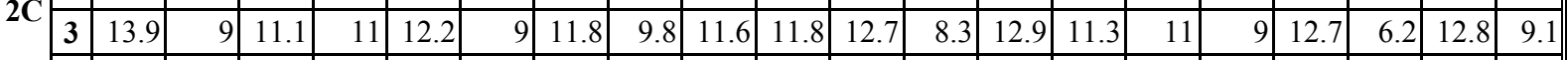

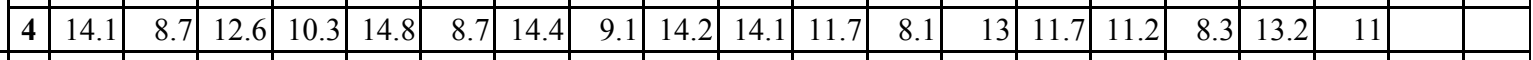

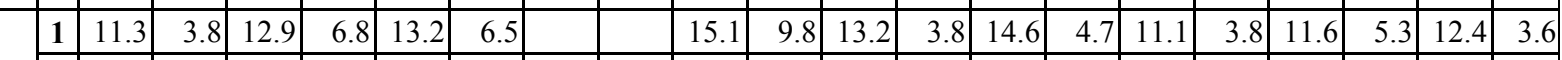

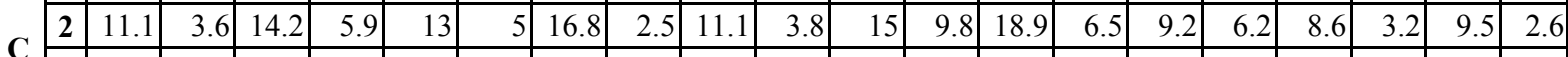

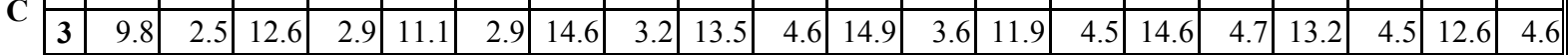

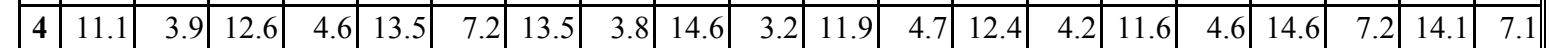
All dimensions are in $\mathrm{cm}$; $\mathrm{C}$ - Control

Table 7. Summary of seed germination results

\begin{tabular}{||c|c|c|c|c|c|c|c||}
\hline \hline Compost & MRL & MSL & MSG\% & RSG\% & RRG\% & GI\% & VI \\
\hline 1A & 11.83 & 11 & 97.5 & 100 & 87.07 & 87.07 & 2228.60 \\
\hline 1B & 13.49 & 7.69 & 82.5 & 84.61 & 99.35 & 84.06 & 1747.59 \\
\hline 1C & 13.93 & 9.81 & 92.5 & 94.87 & 102.56 & 97.30 & 2195.53 \\
\hline $\mathbf{2 A}$ & 11.37 & 7.79 & 90 & 92.3 & 83.70 & 77.25 & 1724.25 \\
\hline 2B & 12.7 & 9.36 & 92.5 & 94.87 & 93.49 & 88.70 & 2040.37 \\
\hline 2C & 13.01 & 9.85 & 90 & 92.3 & 95.81 & 88.43 & 2057.29 \\
\hline C & 13.58 & 5.02 & 97.5 & 100 & 99.97 & 99.97 & 1813.36 \\
\hline
\end{tabular}

MRL- Mean root length; MSL- Mean shoot length; MSG- Mean seed germination; RSG- Relative seed germination; RRG- Relative root growth; GI- Germination index; VI-Vigour index

\section{References}

Fages, J. and Arsac, J.F. 1991. Sunflower inoculation with Azospirillum and other plant growth promoting rhizobacteria. Plant and Soil Journal, Vol.137, pp 87-90. ISSN: 0032-079X
Fang, M., Wong, J.W.C., 1999. Effects of lime amendment on availability of heavy metals and maturation in sewage sludge composting. Environmental. Pollution. Vol 106, pp 83-89. ISSN: 0269-7491

Hue NV, Liu J (1995). Predicting compost stability. Compost Science \& Utilization, Vol 3, pp 8-15. ISSN:1065$657 \mathrm{X}$ 
Iannotti DA, Grebus ME, Toth BL, Madden LV, Hoitink HAJ (1994). Oxygen respirometry to assess stability and maturity of composted municipal waste. Journal of Environmental Quality, Vol 23, pp 1177-1183. ISSN (printed): 0047-2425

Mathur SP, Owen G, Schnitzer H (1993). Determination of compost biomatury. I Literature review. Biology Agriculture and Horticulture, Vol 10,

pp 87-108. ISSN: 0144-8765

Tiquia SM, Tam FY (1998). Elimination of phytotoxicity during cocomposting of spent pig-manure sawdust litter and pig sludge.Bioresource Technology, Vol 65, pp 43-49. ISSN: 0960-8524

Wong JW, Li K, Fang M (2001). Toxicity evaluation of sewage sludges in Hong Kong. Environment International Journal, Vol 27, pp 373-380. ISSN: 0160-4120

Wu L, Ma LQ (2001). Effects of sample storage on biosolids compost stability and maturity evaluation. Jornal of Environmental Quality, Vol 30, pp 222-228. ISSN (printed): 0047-2425

Zucconi F, Pera A, Forte M, de Bertoldi M (1981) Evaluating toxicity of immature compost. BioCycle Vol 22, pp 54-57. ISSN:0276-5055

MSc Manjula Gopinathan - Department of Civil Engineering, Karpagam University, Coimbatore, India.

Main research area: solid waste management E-mail: manju_env@yahoo.com

Dr. Meenambal Thirumurthy - Department of Civil Engineering, Government college of Technology, Coimbatore, India.

Main research area: solid waste management E-mail: tmeenambal_gct@yahoo.co.in 